\title{
MHD Braking and Joules Heating Effect in a Rotating Confined Cylindrical Cavity Packed with Liquid Metal
}

Subas Ch. Dash

Assistant - Professor (SG) Jaypee University of Engineering and Technology, A-B road, Raghogarh,Guna,MP Faculty of Mechanical Engineering India
The present research work investigates the MHD braking and Joules heating effect in a confined rotating cylindrical cavity packed with liquid metal. All walls, except the top and bottom portion of the sidewall, of the cylindrical cavity, are made of electrically as well as thermally conducting material. The cavity is exposed to both axial magnetic fields along with the axial temperature gradient, packed with the incompressible electrically conducting liquid. The MHD braking effect is experienced within the rotating liquid metal flow due to the presence of a strong axial magnetic field. It is discerned that MHD braking governs the primary, as well as secondary flow, and, reduces Joules heating effect. Moreover, the internal heat generation due to Joules heating is governed by rotating speed, Hartmann strength, and temperature gradient.

Keywords:Joules heating; Rotating flow; liquid meta; MHD Braking; incompressible flow.

\section{INTRODUCTION}

In order to control the electrical conducting fluid flow, application of MHD braking in the presence of Joules heating effect can be encountered in various industrial applications, such as liquid metal pumping during the casting process, self-cooled liquid metal blankets in a fusion reactor, geothermal source studies, plasma, MHD power generator, and MHD micro-pump in medical science to circulate blood to maintain sugar level in the blood, etc. The presence of an axial temperature gradient of confined rotating flow in a cylindrical cavity has been investigated by a number of researchers i.e. [1 -5].

In the case of confined axisymmetric swirling flow, the axial magnetic field effect on vortex breakdown as well as on flow stability has been discussed by [6-9]. Flow control in a cylindrical cavity having different cross-sections and configurations was investigated in $[10,11]$.

The effects of the partial rotating lid in the confined cylindrical annulus have been conversed by [12-15]. Rahman et al. [16] have discussed the Joules heating effect on the walls of square lid-driven cavities, with a heated semi-circular source object attached to a wall of the square lid-driven cavities. In the presence of mixed convection, the effect of the magnetic field and Joule parameter were also investigated by them. They have visualized the impact of the direction of moving lid on the flow patterns. In addition, they concluded that the decreasing Joules effect impedes heat flow. In a similar study, [17] has concluded that at the lower Joules heating effect the bulk fluid temperature and heat transfer rate are enhanced.

It had conversed the nature of boundary layer over a rotating disk in a porous medium with hall current and

Received: September 2020, Accepted: January 2021

Correspondence to: Dr Subas Chandar Dash, Faculty of

Mechanical Engineering, Jaypee University of

Engineering and Technology, Raghogarh, India,

E-mail: subas.dash@juet.ac.in

doi:10.5937/fme2102437D

(C) Faculty of Mechanical Engineering, Belgrade. All rights reserved thermal radiation [18]. They concluded that heat transfer is being enhanced under the influence of magnetic field and diminished by incising the Hall current

The effect of the radial magnetic field on the Taylor coquette flow of viscous, incompressible, and electrically conducting fluid have been investigated analytically by [19]. Also, [20, 21] have conducted similar studies. The influence of the axial magnetic field on incompressible electrically conducting fluid, over a stretchable rotating flat surface in the presence of thermal radiation for Nanofluid, have been investigated by $[22,23]$. The effect of the magnetic field in a vertical annulus packed with gallium in the presence of natural convection has been investigated in [24]. They concluded that in the casting process quality products are developed for liquid metal in due to the presence of magnetic field. In [25], the authors have discussed circulation control in MHD rotating flows. They have investigated the 3-D laminar flow in a revolving cylindrical cavity packed with viscous conducting fluid with a braking disc.

It is convinced that the MHD braking in the presence of the Joule heating effect has ben hardly discussed in above reviews. From the above literature reviews, it is felt that MHD braking in a rotating flow with Joules heating within an electrically conducting rotating cylindrical container wall needs to be emphasized. In the present research work MHD braking in the presence of Joules heating effect has been analyzed.

\section{NUMERICAL TECHNIQUE AND SOLUTION PROCEDURE}

In the present study, we considered a confined cylindrical cavity packed with the incompressible, viscous, metallic fluid having Prandtl number 0.015 under the influence of axial magnetic field and axial temperature gradient. The bottom wall, top wall and rotating porting of the sidewall of the cylindrical cavity are electrically as well as thermally conducting as shown in Fig 1. Due to the presence of the electrically conducting wall, in the 
present numerical simulation, the Joules heating effect is considered.

\subsection{Governing Equation}

$T=0$, Conservation of Mass:

$$
\frac{1}{r} \frac{\partial\left(r u_{r}\right)}{\partial r}+\frac{\partial u_{z}}{\partial z}=0
$$

Momentum Equation in radial direction:

$$
\begin{aligned}
& \frac{\partial u_{r}}{\partial t}+\frac{1}{r} \frac{\partial\left(r u_{r} u_{r}\right)}{\partial r}+\frac{\partial\left(u_{r} u_{z}\right)}{\partial z}-\frac{u^{2} \theta}{r} \\
& =-\frac{\partial p}{\partial r}+\frac{1}{\operatorname{Re}}\left[\frac{\partial}{\partial r}\left(\frac{1}{r} \frac{\partial r u_{r}}{\partial r}\right)+\frac{\partial^{2} u_{r}}{\partial z^{2}}\right]+\frac{H a^{2}}{\operatorname{Re}} F_{l r}
\end{aligned}
$$

Momentum Equation in axial direction:

$$
\begin{aligned}
& \frac{\partial u_{z}}{\partial t}+\frac{1}{r} \frac{\partial\left(r u_{r} u_{z}\right)}{\partial r}+\frac{\partial\left(u_{z} u_{z}\right)}{\partial z} \\
& =-\frac{\partial p}{\partial z}+\frac{1}{\operatorname{Re}}\left[\frac{1}{r} \frac{\partial}{\partial r}\left(r \frac{\partial r u_{z}}{\partial r}\right)+\frac{\partial^{2} u_{z}}{\partial z^{2}}\right]+\frac{H a^{2}}{\operatorname{Re}} F_{l z}
\end{aligned}
$$

Momentum Equation in azimuthal direction:

$$
\begin{aligned}
& \frac{\partial u_{\theta}}{\partial t}+\frac{1}{r} \frac{\partial\left(r u_{r} u_{\theta}\right)}{\partial r}+\frac{\partial\left(u_{z} u_{\theta}\right)}{\partial z}+\frac{u_{r} u_{\theta}}{r} \\
& =\frac{1}{\operatorname{Re}}\left[\frac{\partial}{\partial r}\left(r \frac{\partial r u_{\theta}}{\partial r}\right)+\frac{\partial^{2} u_{\theta}}{\partial z^{2}}\right]+\frac{H a^{2}}{\operatorname{Re}} F_{l \theta}
\end{aligned}
$$

Energy Equation:

$$
\begin{aligned}
& \frac{\partial T}{\partial t}+\frac{1}{r} \frac{\partial\left(r u_{r} T\right)}{\partial r}+\frac{\partial\left(u_{y} T\right)}{\partial y} \\
& =\frac{1}{\operatorname{Re} \operatorname{Pr}}\left[\frac{1}{r} \frac{\partial}{\partial r}\left(r \frac{\partial T}{\partial r}\right)+\frac{\partial^{2} T}{\partial y^{2}}\right]+J\left(u_{r}^{2}+u_{\theta}^{2}\right)
\end{aligned}
$$

Equation for Magnetic Flux:

$$
\frac{1}{r} \frac{\partial}{\partial r}\left(r \frac{\partial \Phi}{\partial r}\right)+\frac{\partial^{2} \Phi}{\partial z^{2}}=\frac{u_{\theta}}{r}+\frac{\partial u_{\theta}}{\partial r}
$$

where $F l_{r}, \mathrm{Fl}_{y}$ and $\mathrm{Fl}_{\theta}$ are the Lorentz forces in radial, axial and azimuthal directions respectively and agreed as;

$$
F l_{r}=-u_{r}, F l_{z}=0 \text { and } F l_{\theta}=\frac{\partial \Phi}{\partial r}-u_{\theta}
$$

Boundary Condition:

$$
\begin{gathered}
\text { Top Cold Wall: } z=h, 0 \leq r \leq 1 \\
u_{r}=0, u_{\theta}=0, u_{z}=0, T=-1, \Phi=0
\end{gathered}
$$
Wall

Side insulating and stationary portion of cylindrical

$$
\begin{aligned}
& 0 \leq z \leq 0.5 \times h \text { and } 1.5 \times h \leq z \leq h, \frac{\partial T}{\partial r}=0 \\
& \frac{\partial \Phi}{\partial r}=0 \quad u_{r}=0, u_{\theta}=0, u_{z}=0
\end{aligned}
$$

At side cold rotating cylindrical Wall:

$$
\begin{aligned}
& 1.0 \leq z \leq 2.0 \times h, T=0, \Phi=0 \\
& u_{r}=0, u_{\theta}=\Omega_{\text {Cylinder }} \times r, u_{z}=0
\end{aligned}
$$

At Bottom Wall $z=0,0 \leq r \leq 1$,

$$
u_{r}=0, u_{\theta}=0, u_{z}=0 \quad T=1.0, \Phi=0
$$

\subsection{The solution Procedure}

The solution procedure of momentum equation is based on pressure correction technique [i.e. Modified Mack Method]. The details of the procedure are discussed in [1], [6], [26] and [27]. Energy equation [Eq. 5] is solved by the explicit finite difference approach. The electric potential Equation [Eq.6] has been solved with the help of the over-relaxation technique using the finite difference due to the presence of axial magnetic field. Henceforth, isotherms and Lorentz force are calculated.

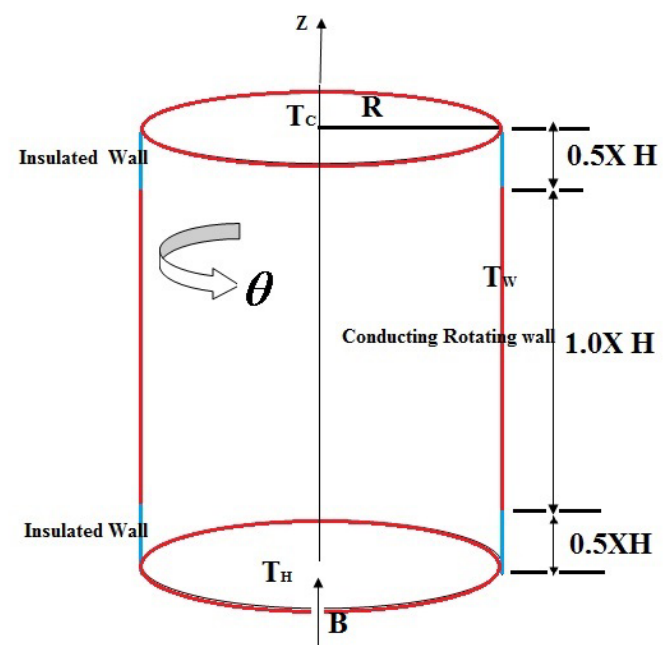

Figure 1. Schematic of rotating cylinder swirling flow in the cylindrical cavity with aspect ratio $H / R$, under the influence of the axial magnetic field and axial temperature gradient

\subsection{Code Validation}

The present code has been validated against the available numerical and analytical solutions of [9] and [10]. A detailed discussion of code validation has been included in my previous published article, [26] and [27] for $\operatorname{Pr}=0.015, \mathrm{AR}=1.0, \mathrm{Re}=100, \mathrm{Ha}=100$.

\section{RESULTS AND DISCUSSION}

\subsection{MHD Braking Effect: Strong Hartmann effect at high Joules heating}

The effect of increasing magnetic field strength on electrical conducting fluid in an electrically conducting cylindrical cavity has been investigated in the presence of joules heating effect in this section. The governing parameters are $\mathrm{Re}=1000, \mathrm{Pr}=0.015, \mathrm{AR}=2.0, \mathrm{Ri}=1.0$, $\mathrm{J}=10$ and $60 \leq H a \leq 200$. The axial profiles of isotherms at $r=0.8$, i.e. near to vertical rotating cylindrical wall indicates that the maximum internal heat generation occurs at $\mathrm{Ha}=60$ and further decreases with increase in Hartmann effect as shown in Fig 2 (a). 
In this axial profile, maximum temperature $T_{\max }=2.5 \mathrm{can}$ be visualized near bottom hot wall i.e. at $\mathrm{r}=0.8, \mathrm{z}=0.4$. However, internal heat generation is reduced to $T_{\max }=2.2$ at $\mathrm{r}=0.8, \mathrm{z}=0.8$ for $\mathrm{Ha}=200$. A peculiar observation can be seen from Fig 2 (b), Fig 2(c) and Fig 2(d).

It is clearly observed that with increasing Hartmann strength an MHD Braking is developed within flow. Both axial profiles of radial component velocity along the axis and radial profiles of azimuthal velocity along the radius reduce to zero. Hence, it concluded that primary flow and radial flow within the core of cavity are clogged with increase in Hartmann strength.

Hence, it is concluded that primary and radial flows within the core of the cavity are clogged. The presence of axial magnetic field develops Lorentz force in radial and azimuthal directions (i.e $F l_{Z}, F l_{r}$ ) respectively. Hence, MHD braking is developed, which restricts primary flow in azimuthal direction and radial flow in radial direction in the presence electrical conducting rotating cylinder. Since the presence of axial magnetic field could not develop any Lorentz force in axial direction, only axial flow is subsisted within the liquid metal.

Due to this imperative aspect of the condition, internal heat generation is reduced during MHD braking process.

Since the flow is restricted within the core of the cavity, the convective mode of heat transfer is predominated by conduction mode of heat flow. The Nusselt number magnitudes near bottom-hot, top-cold and side-rotating cold walls are shown in Fig 3. The maximum magnitude of the Nusselt number near side rotating wall indicates that the convective heat flow dominates the conduction mode of heat transfer near it.

(a)

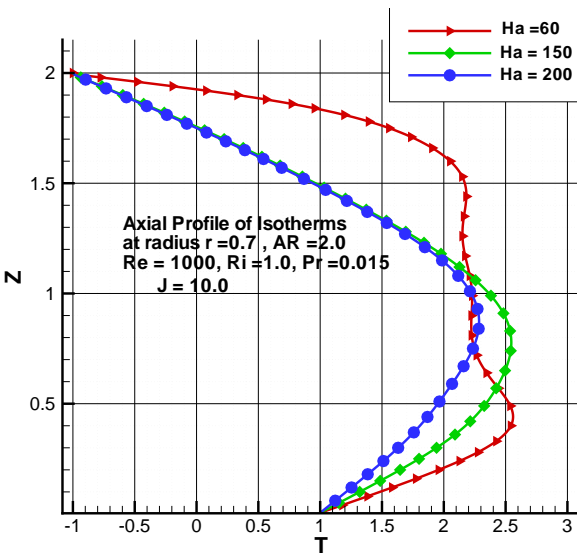

(b)

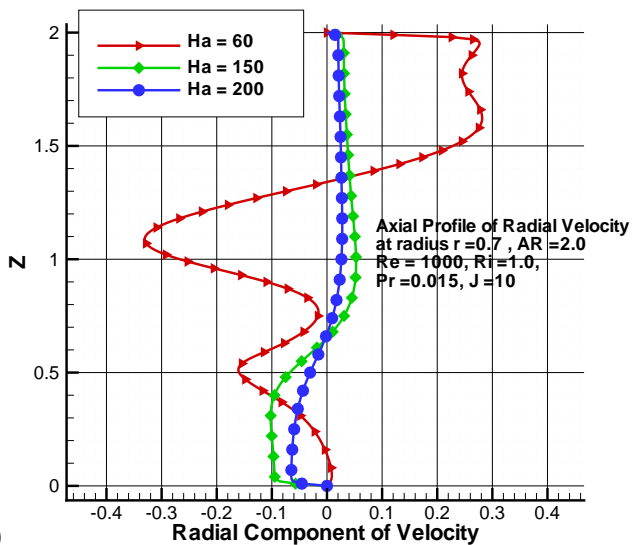

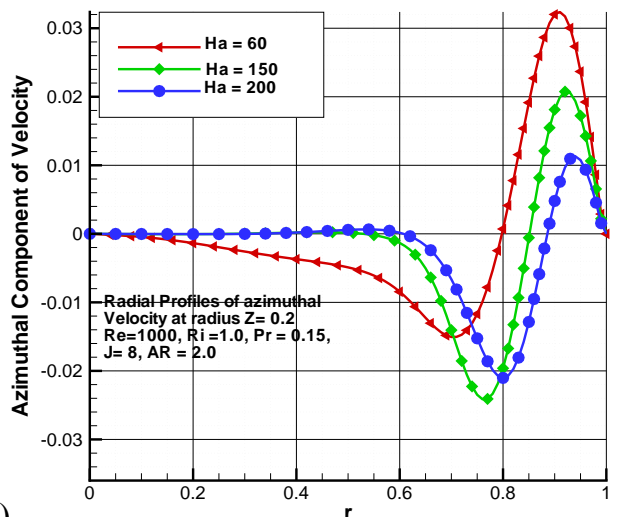

(c)

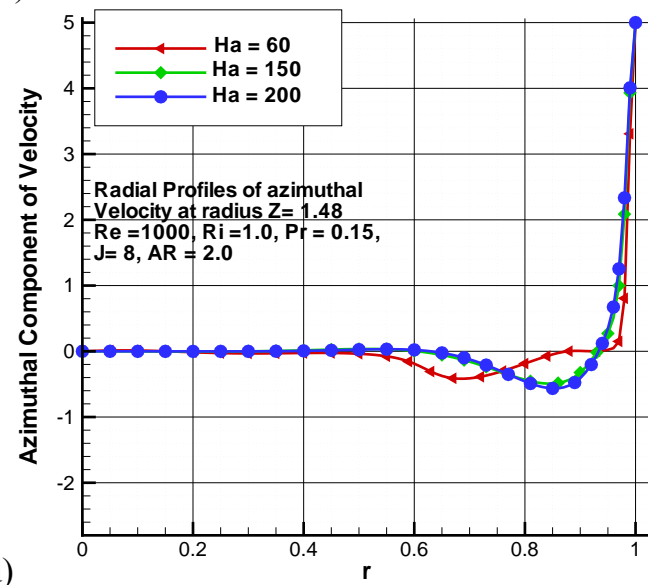

(d)

Figure 2. Axial profile of (a) isotherms and (b) radial velocity at $r=0.7$; Radial profile of azimuthal velocity at (c) $z=0.2$, (d) $z=1.48$ : at different Hartmann number where where $\Omega_{\text {Cylinder }}=5 \times r$ at $0.5 \leq z \leq 1.5$

However, the magnitude of $\mathrm{Nu}$ decreases with increase in Hartmann strength at all locations. Hence, it is a clear indication of $M H D$ braking effect which dominants the Joules heating effect. It endorses that during the MHD braking internal heat generation is damped within the core of the fluid, which also can be interpreted from Fig 2(a)

\subsection{JOULES Heating and MHD Braking Effect at different Richardson Number (Ri): \\ at $\left[\Omega_{\text {Cylinder }}=0.5 \times r\right.$ at $\left.0.5 \leq z \leq 1.5\right]$ :}

The impact of axial heat transfer in the presence of strong magnetic field $(\mathrm{Ha}=200)$ on Joules heating and MHD braking observed in this section. There are no extensive changes in the magnitude of isotherms with an increase in Richardson number shown in Fig 4(a).

Hence, it is clear that under the influence of the strong axial magnetic field on the axial heat transfer has very little impact on joules heating effect and internal heat generation. It is clear from the axial profile of the radial component of velocity that the magnitude of velocity is near about zero at $\mathrm{Ri}=1.0$. Nevertheless, the magnitude has been intensified with exaggeration in Richardson's number, Fig 4 (b).

In this particular condition, the liquid metal has no motion in the azimuthal direction, which can be interpreted from Fig 4 (c) and Fig 4 (d); the azimuthal component of the velocity remains zero within the maximum portion of the core region of the cavity. Moreover, 
the MHD braking effect can be sensed in an azimuthal direction (i.e- Azimuthal plane) not in an axial direction (i.e.- meridional plane) in the presence of strong magnetic field even at high axial temperature gradient.

Due to increase in Richardson number, an axial temperature gradient heat flow enhanced, henceforth the buoyancy effect in axial direction dominates the flow.

However, the presence of a strong axial magnetic field slows down the buoyancy effect, flow velocity, and convective heat flow rate dominated by conduction mode of heat transfer within the core. The magnitude of the average Nusselt number, near the bottom hot wall, at different joules parameters with an increase in Richardson number can be seen in Fig 5 (a).

a)
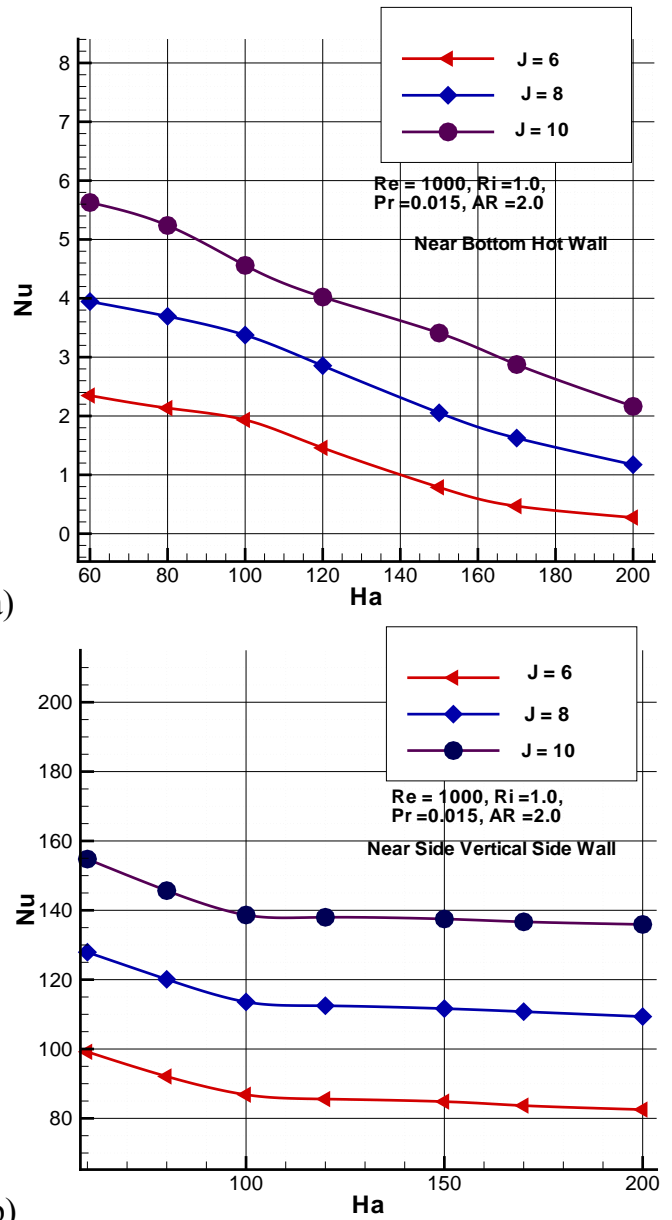

(b)

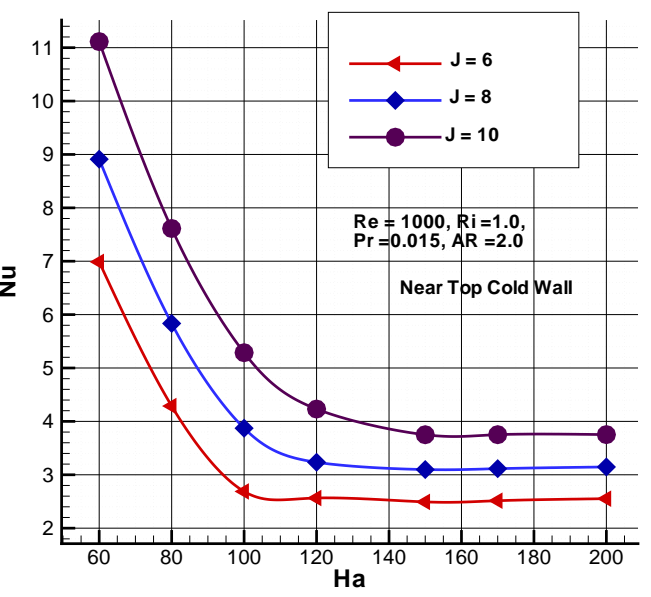

(c)

Fig: 3 Nusselt number profiles at different $\mathrm{Ha} \mathrm{(a)} \mathrm{near}$ bottom hot wall (b) near side vertical wall (c) near top cold wall.
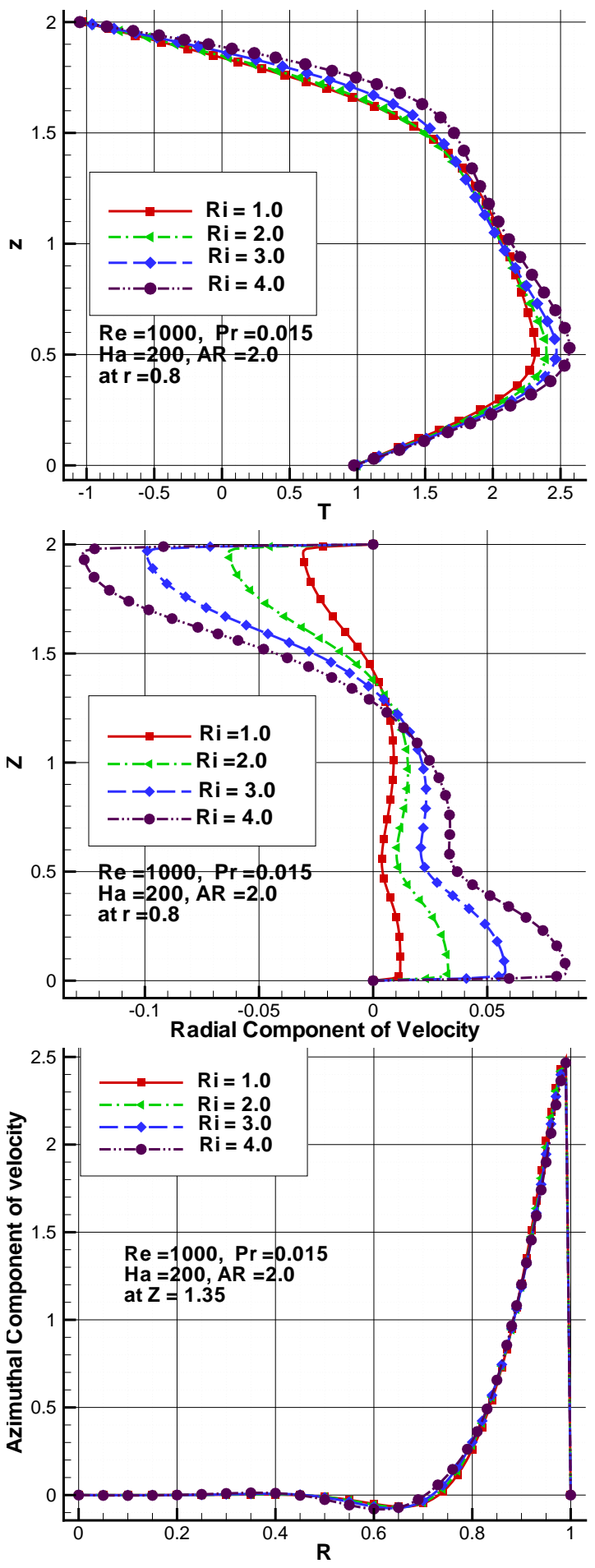

Figure 4. Axial profile of (a) isotherms and (b) radial velocity at $r=0.8$; and radial profile of Azimuthal velocity at (c) $z=0.2$, (d) $z=1.48$ : at different Richardson number. Where [ $\Omega_{\text {Cylinder }}=5 \times r$, at $0.5 \leq z \leq 1.5$ ].

At $\mathrm{J}=4$, the impotence of $\mathrm{Ri}$ on $\mathrm{Nu}$ is interpreted. At higher magnitude of $\mathrm{J}=6$ and 8 , the magnitude of $\mathrm{Nu}$ increases with increase in $\mathrm{Ri}$. It indicates that the axial temperature gradient has a significant effect on convection heat transfer only at higher Joules parameter, which can be seen in the presence of the strong axial magnetic field. Near the side rotating cold wall, Richardson number has insignificant effect on the Nusselt number shown in Fig 5 (b). However, near the top cold stationary wall, the Richardson number effect can be interpreted from Fig 5 (c). 

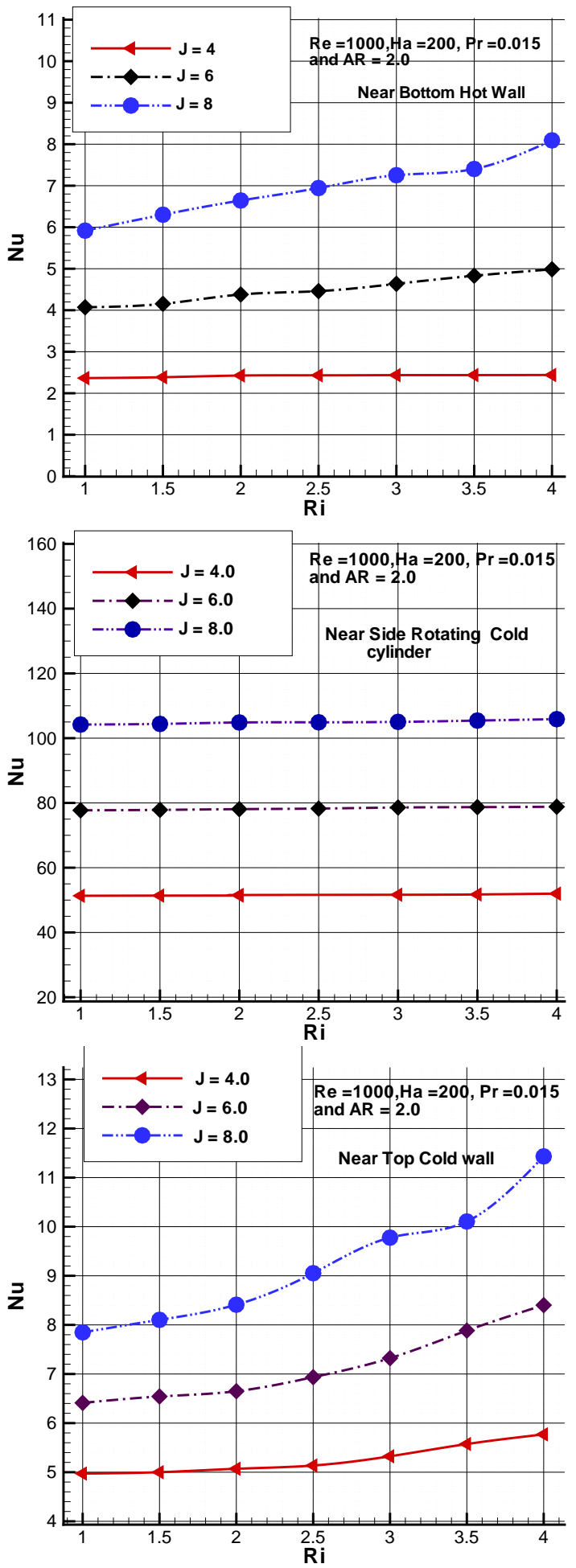

Fig: 5 Nusselt number profiles at different $\mathbf{R i}$ (a) near bottom hot wall (b) near side vertical wall (c) near top cold wall

The MHD braking effect remains stronger at the mid portion of the core of the cavity (i.e. at the mid portion of electrically conducting rotating-cold cylinder) in liquid metal flow at $\mathrm{z}=1.0$ even at $\mathrm{Re}=3000$.

The mode of heat transfer in the vicinity of the bottom hot wall can be seen from Fig 6 (a) due to increase in Joules heating effect. It is interesting to visualize that the magnitude of $\mathrm{Nu}$ decreases with an increase in Joules heating. This is due to internal heat generation in the core of the cavity, which generates an adverse temperature gradient from the hot plate to the core of the cavity. However, in the vicinity of the top stationary cold wall and side rotting cold wall, magnitude of $\mathrm{Nu}$ increases with the increase in Joules heating effect, as shown in Fig 6 (b) and Fig 6 (c). Hence, it can be concluded that the convection heat flow dominates over conduction heat transfer at higher Joules heating effect with increase in Reynolds number $\Omega_{C y l i n d e r}=0.5 r$ but the momentum diffusivity varies with increase in Re due to internal heat generation) ranging near the cold surface.
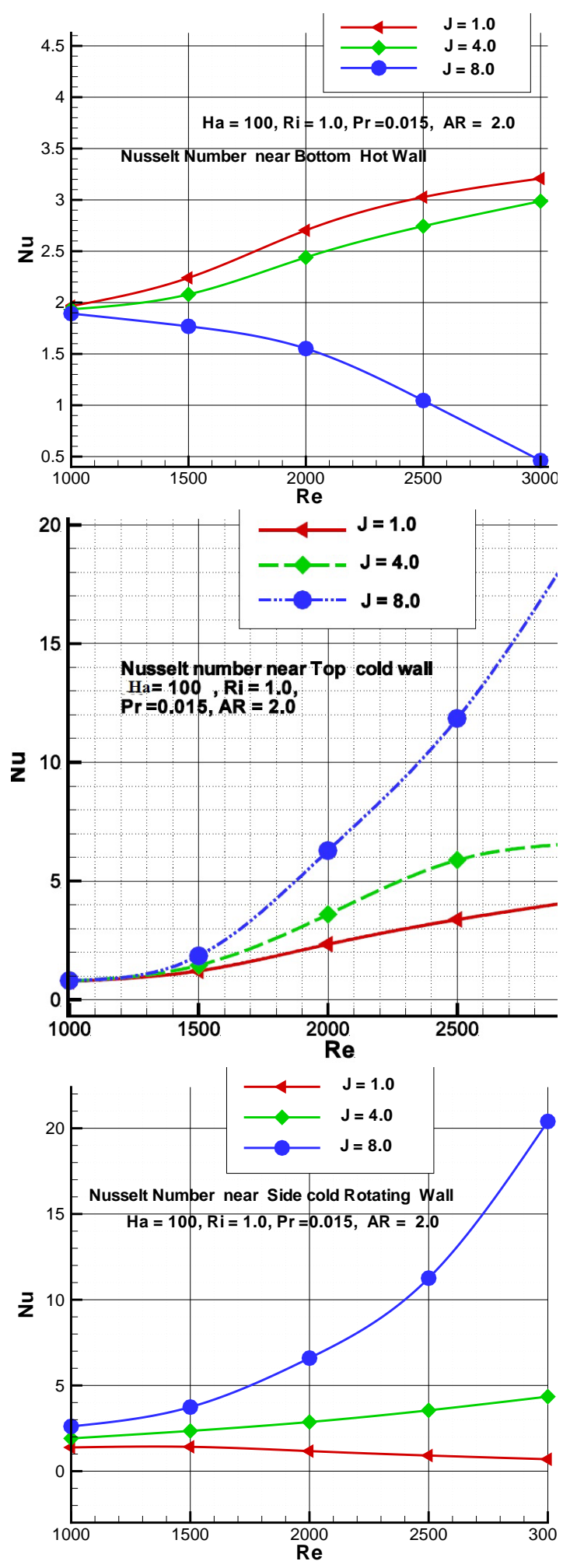

Fig: 6 Nusselt number profiles at different $\operatorname{Re}(a)$ near botto hot wall (b) near side vertical wall (c) near top cold wa 


\section{CONCLUSION}

The effects of MHD braking in the presence of Joules heating are investigated. The MHD braking effect becomes stronger in the presence of strong axial magnetic field, which controls both the primary and secondary flows.

A strong axial temperature gradient has rare effect on MHD braking in azimuthal direction and only disturbs the MHD braking effect in axial direction.

At higher Reynolds number, the effect of MHD braking effect is reduced and internal heat generation is encouraged within the flow. With the increase in the Joules heating parameter, the conduction mode of heat transfer dominates the convection at higher Re near bottom hot wall.

However, in the presence of strong Joules heating parameter the convective heat flow dominates conduction mode of heat transfer vicinity of vertical rotating cold cylinder and top stationary cold wall with an increase in Reynolds number.

Only by increasing the rotating speed of the cylindrical wall, the convective heat flow dominates conduction throughout the cavity. The MHD braking effect analyzed in the present study can be implemented in industrial applications, particularly to control the electrically conducting fluid flow and internal heat generation. In case of the braking system of machines, MHD braking can be employed.

\section{ACKNOWLEDGMENT}

This work has been supported by Thermal Laboratory, Mechanical Engineering Department, Jaypee University of Engineering and Technology, A-B Road, GUNA, MP, INDIA. I am Very much thankful to the faculty members of my Mechanical Engineering Department for their kind support. Special thanks to Mr. Manoj Dubey, Mr. Amiya Sahoo,Mr Pankaj Dumka.

\section{REFERENCES}

[1] Dash, S. and Singh, N.: Effects of partial heating of top rotating lid with axial temperature gradient on vortex breakdown in case of axisymmetric stratified lid driven swirling flow, Yildiz Technical University Press, Istanbul, Turkey, J. Thermal Eng, 2, pp. 883- 896, 2016.

[2] Lugt HJ, Abboud M.: Axisymmetric vortex breakdown with and without temperature effects in a container with a rotating lid. J of Fluid Mech, Vol.179, pp. 179-200, 1987

[3] Kim WN, Hyun JM.: Convective heat transfer in a cylinder with a rotating lid under stable stratification, Int. J Heat and Fluid Flow. Vol. 18, No 4, 384-388, 1997.

[4] Lee CH, Hyun JM. Flow of a stratified fluid in a cylinder with a rotating lid. Int $\mathrm{J}$ heat and fluid flow, Vol. 20, No 1, pp. 26-33, 1999.

[5] Iwatsu R.: Flow pattern and heat transfer of swirling flows in cylindrical container with rotating top and stable temperature gradient, Int. J Heat Mass Transfer. Vol. 47, N0.12, pp. 2755-2767, 2004.
[6] Dash, S. and Singh, N. Study of axisymmetric nature in 3-d swirling flow in a cylindrical annulus with a top rotating lid under the influence of axial temperature gradient or axial magnetic field, $\mathrm{J}$ of Thermal Eng, Vol. 6, No. 3, pp.1588-1606, 2017.

[7] Gelfgat YM, Gelfgat AY.: Experimental and numerical study of rotating magnetic field driven flow in cylindrical enclosures with different aspect ratios, Magneto hydrodynamics, Vol. 40, No. 2, pp147-160, 2004.

[8] Bessaih R, Marty P, Kadja M.: Numerical study of disk driven rotating MHD flow of a liquid metal in a cylindrical enclosure, Acta Mechanica, Vol. 135, No 3, pp.153-167, 1999.

[9] Bessaih R., Kadja M, Eckert K, Marty P.: Numerical and analytical study of rotating flow in an enclosed cylinder under an axial magnetic field, Acta mechanica, Vol. 164, No.3, pp.175-188, 2003.

[10] Yu P, Lee TS, Zeng Y, Low HT.: Characterization of flow behavior in an enclosed cylinder with a partially rotating end wall, Phy of fluids, Vol. 19, No 5, pp. 057104, 2007.

[11] Naumov IV, Dvoynishnikov SV, Kabardin, IK, Tsoy M.A.: Vortex breakdown in closed containers with polygonal cross sections, Phys. of Fluids, Vol. 27, No 12, pp. 124103, 2015.

[12] Jørgensen BH, Sørensen JN. Aubry N.: Control of vortex breakdown in a closed cylinder with a rotating lid, Theo. and Comp. Fluid Dynamics, Vol. 24, No. 5, pp 483-496, 2010.

[13] Mununga L., Jacono DL., Sørensen JN, Leweke T, Thompson MC, Hourigan K.: Control of confined vortex breakdown with partial rotating lids, J Fluid Mech. Vol. 738, No 5, pp. 33, 2014.

[14] Herrada M A, Shtern V.: Vortex breakdown control by adding near-axis swirl and temperature gradients, Physical Review E, Vol. 68, No 4, pp. 041202, 2003.

[15] Husain HS, Shtern V, Hussain, F.: Control of vortex breakdown by addition of near-axis swirl, Phy. of Fluids, Vol. 15, No. 2, pp. 271-279, 2003.

[16] Rahman MM, Öztop HF, Rahim NA, Saidur R, AlSalem K.: MHD mixed convection with joule heating effect in a lid-driven cavity with a heated semi-circular source using the finite element technique, Numer. Heat Transfer, Part A: Applications, Vol. 60, No. 6, pp. 543-560, 2011.

[17] Chatterjee D, Halder P, Mondal S, Bhattacharjee S.: Magnetoconvective transport in a vertical lid-driven cavity including a heat conducting square cylinder with Joule heating, Numer. Heat Transfer, Part A: Applications, Vol. 64, No. 12, pp.1050-1071, 2013.

[18] Rahman MM, Öztop HF, Rahim NA, Saidur R, AlSalem K.: MHD mixed convection with joule heating effect in a lid-driven cavity with a heated semi-circular source using the finite element technique, Numer. Heat Transfer, Part A: Applications, Vol. 60, No. 6, pp. 543-560, 2011. 
[19] Jha BK., Jibril HM, Emeka, A O.: Role of radial magnetic field on heat transfer in MHD Couette flow in an annulus with viscous and Joule dissipation, Thermo physics and Aeromech. Vol. 25, No. 2, pp. 289-297, 2018.

[20] Ram P, Kumar V.: Swirling flow of field dependent viscous ferrofluid over a porous rotating disk with heat transfer, Int. J. Appl. Mech, Vol. 6, No. 04, pp. 1450033, 2014.

[21] Ram P, Joshi VK, Sharma K, Walia M, Yadav N.: Variable viscosity effects on time dependent magnetic nano fluid flow past a stretchable rotating plate, Open Phys, Vol. 14, No. 1, pp. 651-658, 2016.

[22] Ram P, Joshi VK, Sharma S, Yadav N.: Boundary layer flow of magnetic nanoliquids due to a radially

rotating stretchable plate, Int. Materials Sci. Foru. Vol. 928, pp.100-105, 2018.

[23]Ram P, Joshi VK, Kumar V, Sharma S.: Rheological Effects Due to Oscillating Field on Time Dependent Boundary Layer Flow of Magnetic Nanofluid Over a Rotating Disk, Proceedings of the National Academy of Sciences, India Section A: Phys Sci. Vol. 89, N0. 2, pp.367-375, 2019.

[24] Afrand, M., Toghraie, D., Karimipour, A. and Wongwises, S.: A numerical study of natural convection in a vertical annulus filled with gallium in the presence of magnetic field, J. of Magnetism and Magnetic Materials, Vol. 430, pp.22-28, 2017.

[25] Borisevich, V.D., Potanin, E.P. and Whichello, J.: Circulation control in magnetohydrodynamic rotating flows, J. of Fluid Mech, Vol. 829, pp.328344, 2017.

[26] Dash, S.C. and Singh, N.: Influence of axial magnetic field on swirling flow and vortex breakdown zones in a cylindrical cavity with a rotating lid,

[27] Int. J. of Applied Mechanics, Vol. 11, No.06, pp.1950054, 2019.

[28]Dash, S.C. and Singh, N.: Effect of a strong axial magnetic field on swirling flow in a cylindrical cavity with a top rotating lid, Int. J. of Modern Phy. C, Vol. 30, No.11, pp.1950092, 2019.

\section{NOMENCLATURE}

$\begin{array}{ll}h=H / R & \text { Cylinder aspect ratio[-] } \\ B & \text { A non-dimensional term. } \\ H & \text { Magnetic Field [kg/s3A] } \\ \mathrm{R} & \text { Height [m] } \\ p & \text { Radius[m] } \\ r, \theta, z & \text { Non-directional Pressure[-] } \\ T_{H} & \text { Non-dimensional, Radial, azimuthal } \\ T_{C} & \text { and axial coordinate[-] } \\ \mathrm{T} & \text { Temperature of bottom hot wall in [K] } \\ T_{\max } & \text { Temperature of the top cold wall in } \\ & \text { [K] } \\ & \text { Non-dimensional Temperature [-] } \\ & \text { Non-dimensional Maximal }\end{array}$

t Non-dimensional time[-]

$u_{r}, u_{\vartheta} u_{z} \quad$ Non-dimensional Radial, Azimuthal and Axial velocity components.[-]

$F l_{r} \mathrm{Fl}_{y}, \mathrm{Fl}_{\theta} \quad$ Lorentz forces in radial, axial and azimuthal directions[N]

\section{Non-dimensional numbers}

$$
\begin{array}{ll}
R i=\left\{\frac{g \beta \Delta T R}{R \Omega^{2}}\right\} & \text { Richardson number[-] } \\
\mathrm{J} & \text { Joule heating parameter[-] } \\
N u_{L}=\left.\frac{\partial T}{\partial y}\right|_{y=h} & \text { Local Nusselt number[-] } \\
N u=\frac{1}{\pi} \int N u_{l}(r) 2 \pi d r & \text { Average Nusselt number[-] } \\
H a=B R \sqrt{\frac{\sigma}{\mu}} & \text { Hartmann number[-] } \\
N=\frac{H a^{2}}{\operatorname{Re}} & \text { Interaction parameter[-] } \\
\operatorname{Pr}=\frac{v}{\alpha} & \text { Prandtl Number[-] } \\
\operatorname{Re}=\frac{R^{2} \Omega_{C y l i n d e r}}{v} & \text { Reynolds Number[-] }
\end{array}
$$

\begin{tabular}{|c|c|}
\hline$\Phi$ & electric potential \\
\hline$\Phi^{*}$ & Non-dimension electric potential \\
\hline $\boldsymbol{V}$ & kinematic viscosity $[\mathrm{m} 2 / \mathrm{sec}]$ \\
\hline 2 & $\begin{array}{l}\text { Constant angular speed of cylinder } \\
{[\mathrm{rad} / \mathrm{Sec}]}\end{array}$ \\
\hline & Electrical conductivity $[\mathrm{S} / \mathrm{m})]$ \\
\hline$u$ & dynamic viscosity $[\mathrm{Pa} \times \mathrm{s}]$ \\
\hline$\chi=\frac{k_{l}}{\rho C_{p}}$ & thermal diffusion $\left.\left[\mathrm{m}^{2} \mathrm{~s}^{-1}\right)\right]$ \\
\hline 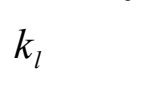 & $\begin{array}{l}\text { thermal conductivity of the liquid metal } \\
{[\mathrm{W} / \mathrm{m} . \mathrm{K}]}\end{array}$ \\
\hline$C_{n}$ & $\begin{array}{l}\text { Coefficient of heat at constant pressure } \\
{[\mathrm{kJ} / \mathrm{kg} . \mathrm{K}]}\end{array}$ \\
\hline 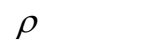 & density of liquid metal $\left[\mathrm{kg} / \mathrm{m}^{3}\right]$ \\
\hline
\end{tabular}

\section{Greek symbols}

\section{МАГНЕТОХИДРОДИНАМИЧКО КОЧЕЊЕ И ЏУЛОВ ЕФЕКАТ ЗАГРЕВАЊА КОД РОТИРАЈУЋЕ ОГРАНИЧЕНЕ ЦИЛИНДРИЧНЕ ШУПЉИНЕ ПУЊЕНЕ ТЕЧНИМ МЕТАЛОМ}

\section{С.Ч. Даш}

Истражује се МХД кочење и Џулов ефекат загревања код ротирајуће ограничене цилиндричне шупљине пуњене течним металом. Сви зидови цилиндричне шупљине, осим врха и дна бочних зидова, израђени су од материјала електричне и топлотне проводљивости. Шупљина је изложена аксијалном магнетном пољу са аксијалним градијентом температуре и пуњена је нестишљивом електрично проводљивом 
течношћу. Ефекат МХД кочења се јавља код ротационог струјања течног метала услед присуства јаког аксијалног магнетног поља. Утврђено је да МХД кочење управља примарним као и секундарним струјањем и утиче на опадање Џуловог ефекта загревања. Брзина ротације, Хартманова чвстоћа и градијент температуре утичу на генерисање унутрашње топлоте под дејством Џуловог ефекта. 